\title{
BRIEF CONSIDERATIONS ABOUT THE IMPORTANCE OF SIGN LANGUAGE AND INTERPRETERS PRESENCE IN ATTENDING DEAF TEENAGER LAWBREAKERS: A BRAZILIAN PERSPECTIVE
}

\author{
Ana Caroline Santana \\ Curso de Mestrado Profissional em Diversidade e Inclusão (CMPDI), Universidade Federal \\ Fluminense, RJ, Brazil. \\ Elenilde Maria dos Santos \\ Curso de Mestrado Profissional em Diversidade e Inclusão (CMPDI), Universidade Federal Fluminense, \\ RJ, Brazil. \\ Helena Carla Castro \\ Curso de Mestrado Profissional em Diversidade e Inclusão (CMPDI), Universidade Federal Fluminense, \\ RJ, Brazil.

\begin{abstract}
During the appliance of social-educational measurements on teenager lawbreakers, it is essential to be able to evaluate their evolution and personal development. For a positive follow-up it is necessary the involvement of these adolescents, their family and the team of the unit that attend them. On that purpose these actors should be able to communicate extensively among themselves. This is mainly due to the fact that it is necessary to identify the circumstances that led the teenager to commit the infraction. Based on this knowledge, the guidelines and interventions can be planned to lead the teenager to reflect about his/her actions. In Brazil, the legislation advocates the rights and duties for adolescents and defines Communication as the way that the Brazilian citizens interact with each other, whether through the use of languages, including sign language, and/or other forms (eg. Braille, signaling system or tactile communication). The purpose of this article is to highlight the importance of the use of sign language and interpreters when attending deaf teenager lawbreakers or those in which parents or legal guardians are deaf in order to allow the safe and successful return of these teenagers back to the society.
\end{abstract}

Keywords: Social-educational Measurements; Communication; Deaf; sign language 


\title{
I. INTRODUCTION
}

In Brazil, individuals under 18 years old that commit an infraction should be arrested and presented to the competent police authority, preferably to the Police Department for Protection of Children and Adolescents (DEPCA). Then, after listening to the witnesses, a restriction order will be issued and later, in the presence of the Public Prosecutor, an advisory service will be determined for these individuals that in this work will be called adolescent or teenager $[1,3,5]$.

\begin{abstract}
"Among other rights and guarantees, those listed below: (...) full defense; Right to silence; Right not to produce evidence against yourself; legal defense by a public lawyer, from the presentation to the Public Prosecutor; Information about his/her rights; Identification of those responsible for his/her arrest; Right to be heard in person by the competent authority; Right to be accompanied by parents or guardians; Free legal assistance and double degree of jurisdiction. "(SINASE, 2006: 27)
\end{abstract}

After the hearing(s), if the selection of the social-educational measurement (SEM) involves take the adolescent into custody or semi-freedom, in Brazil it is essential to perform meetings with the adolescent, his/her family and the technical team during this period. This procedure aims to understand the circumstances that led the adolescent to commit the illegal act, and to (re)approach him/her to his/her family life. In addition, when it is necessary, it is established goals to be reached with and by the adolescent to contribute to his/her reflection and commitment with his/her own future [5].

The successful and clear communication among all involved in the accomplishment of the SEM is an essential factor to have positive results. The literature reported that the dialogues with speaking and listening moments become very important from the very moment of the adolescent apprehension. In order to apply or not the SEM to the adolescent, it is necessary first to listen to all involved, and then to determine the sentence. The listening of the adolescent's speech by the team of the unit is also determinant to contribute to the change of his/her attitudes. Besides the hearing, it is important to really listening to what the adolescent is saying, making available to establish better forms of strategies and interventions to be performed with and by him/her. $[5,6]$

"...unlike authoritarianism which arbitrarily establishes a single point of view...technicians and educators are responsible for directing actions, ensuring the participation of the adolescents and stimulating ongoing dialogue. "(SINASE, 2006: 48)

The Brazilian educational agents try to focus towards accessibility and inclusion in their pedagogical practices. On this perspective, deafness is one issue that should not be forgotten. This issue enlightens and reinforces the importance of the dialogue among the actors (adolescent, family and/or their legal guardian (s), educational agents) involved in the implementation and accompaniment of the SEM application on the deaf adolescent in conflict with the law.

\section{SOCIAL-EDUCATIONAL MEASURE (SEM) INVOLVING FREEDOM RESTRICTION}

According to the Brazilian National System of Social-Educational Assistance (SINASE), the objective of the SEM is "to enable social inclusion in a more rapid way and, especially, the full development as a person" (SINASE, 2006: 28).

In Brazil, the adolescent of 12 to 18 years who is found committing an infraction, after a legal process, may receive a SEM that will vary according to his/her involvement in the situation and its seriousness/gravity. [2, 3]. According to the Brazilian Statute of the Child and Adolescent - ECA, 1990, the SEM can be: $i$ ) warning; ii) obligation to repair the damage; iii) community service and assisted freedom; $i v$ ) restrictive of freedom: semi-liberty and internment/taken in custody.

During SEM involving freedom restriction, the need for communication becomes even more important, since the discourses may: a) approach the adolescent and those who in charge, b) contribute to understand the reasons that led to the act committed, and c) guide the planning of the activities to be proposed to the adolescent. They will also reveal situations that need to be addressed with the adolescent, such as focusing on strengthening family relationship. According to Cardoso: 
"Communication is an interaction process in which we share messages, ideas, feelings and emotions. It occurs by means of written and spoken language, besides non-verbal mechanisms like gestures, corporal expressions, images, touch and other signs." (Cardoso et al, 2006: 554)

The technical assistance aims to contribute positively to the formation of the teenagers' rational judgment, seeking to promote the reflection about their actions, through social-educational actions. They include: a) obtain their civil documentation and assistance in the Health area when necessary; B) (re)insertion and follow-up in the process of vocational schooling, sport and culture; C) access to religious assistance, among others.

One of the instruments carried out by the Brazilian educational agents is the Individual Care Plan (PIA), which should be elaborated after studying each case. This study evaluates the adolescent participation, his/her family or legal guardians and the educational agents as well, thus enabling that the actions proposed reflect his/her needs respecting his/her affinity areas and abilities.

"The social-educational action must respect the phases of integral development of the adolescents taking into account their potentialities, their subjectivity, their capacities and their limitations, guaranteeing the particularization in their accompaniment. Therefore, the individual service plan (PIA) is a fundamental pedagogical instrument to guarantee equity in the social-educational process. "(SINASE, 2006: 48)

The adolescent in compliance with freedom restriction should have the development of his/her activities accompanied and re-planned, if necessary, by the team, together with continuously dialogue in this process. The same should happen with the SEM plan that should be reevaluated continuously in a maximum period of six months. $[3,5]$

\section{THE DEAF IN COMPLIANCE WITH THE SEM}

Deafness can be classified according to the difficulty of hearing as: mild, moderate, severe or profound. It can be caused by congenital origin (derived from diseases developed during pregnancy) or be acquired due to diseases such as meningitis, among others [8].

In order to establish a communication between two people, it is necessary to have a language that represents the thinking of who dialogues. The form of communication used by the deaf people can be oral (eg. Portuguese language) or gestual (eg. Sign Language), being defended by the Brazilian deaf community the use of LIBRAS, the Brazilian sign language that is considered their native, natural and first language (L1). [7]

As mentioned before, the dialogue among the educational agents, the adolescent and his/her family is essential for the fulfillment of SEM in a positive and successful way. Therefore it is fundamental that all people involved in this process actually understand the adolescent lawbreaker, including especially those with disabilities, which is cited in the Brazilian law.

"The Federal Constitution provides that the person with disabilities should receive special attention from the State and society ... the adolescent should receive treatment that respects the peculiarities of his/her condition, so as to avoid being in a position of risk and disadvantage in the social-educational system. "(SINASE, 2006: 29)

The question is what happens when the teenager and/or his/her legal guardian/family is deaf and how to manage this situation that clearly creates difficulties in the communication among all involved. If the Brazilian deaf adolescent lawbreakers and/or their deaf parents use the Portuguese language, orally or writing, their attendance may occur through oral communication and/or using questions and answers in the written form. However if they use LIBRAS, an interpreter or a bilingual agent is required in order to guarantee the full communication and to perform it satisfactorily. [10,11]

"Public service providers, financial institutions and direct and indirect public administration bodies should enable differentiated treatment of the deaf through the use of LIBRAS and the 
translation and interpretation of LIBRAS and Portuguese Language, carried out by Servers and employees trained for this function. "(Law 10.436, art.7)

The technical assistance given to the adolescent and his/her guardians must be confidential, as they address confidential matters. Therefore it is important the presence of a qualified professional capable of interpret/translate with fidelity assuring the right of the deaf and to contribute to the fulfillment of SEM in a positive way, so he/she can be reinserted into the society (Figure 1).

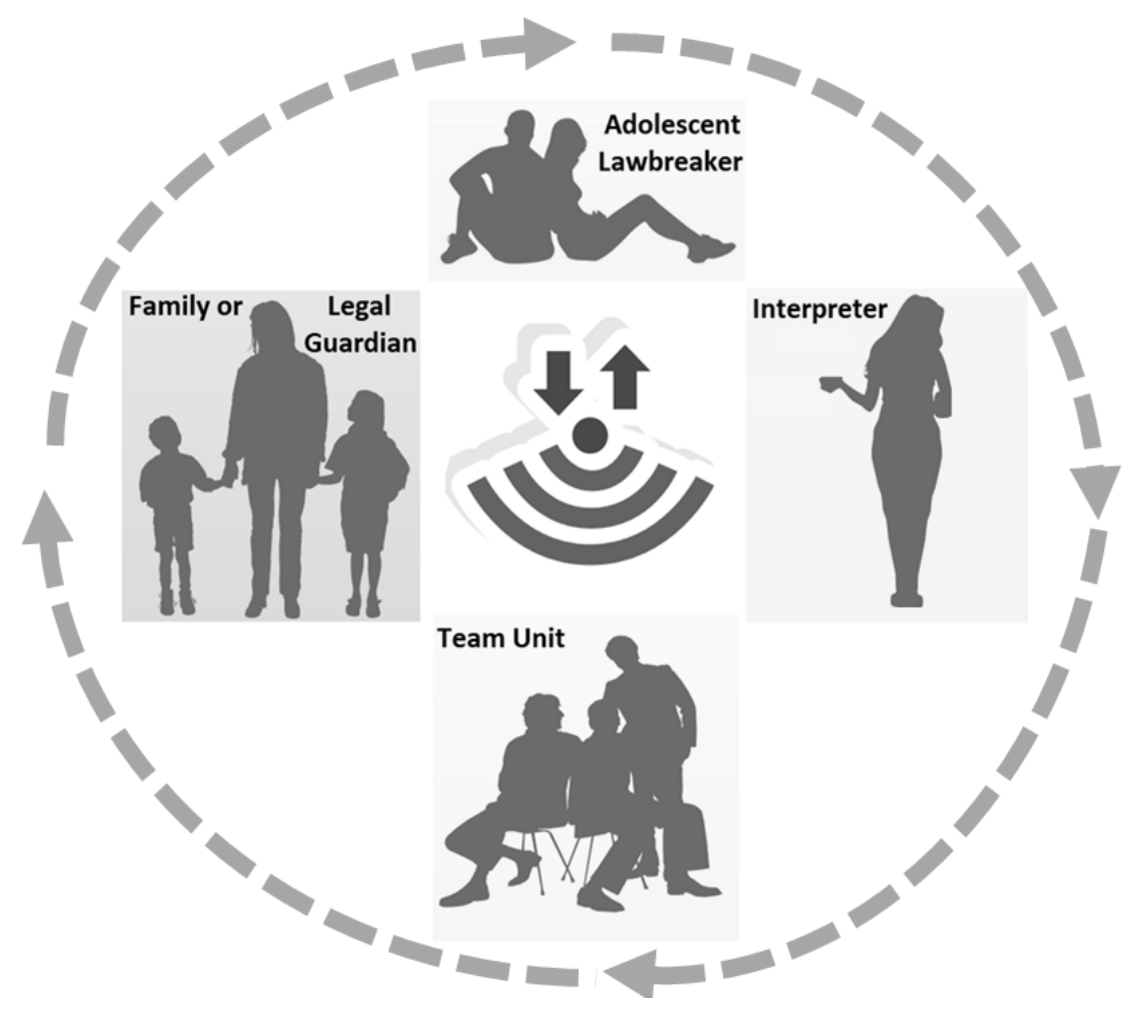

Figure 1: The deaf adolescent lawbreaker should be attended with quality involving a multidisciplinary team unit, the family or legal guardian, and with the help of an interpreter if the team unit does not know sign language. The dashed lines represent the communication necessary among all involved in the task of a successful recovery and return of the lawbreaker to the society. Figure created using vectors from https://www.vecteezy.com/free-vector.

It is also important to consider the psychological aspects involved such as the confidence and trust of the adolescent in telling the truth to and through the interpreter, which may be an obstacle for the successful execution of the SEM. On that matter, the involvement of an interpreter that already know the adolescent may help depending of the relationship with him/her. The most important point is to not ignore the feelings of the adolescent and his/her personal profile in order to get him/her back to the society decreasing the statistic level of criminality re-incidence.

Knowing that the adolescent feelings are of importance in this legal regeneration process, communication is even more essential for the deaf that already has personal issues about his/her condition.

"If you talk to a man in a language he understands, that goes into his head. If you speak to him in his own language, you reach his heart" (Nelson Mandela)

\section{REFERENCES}

1. ARAÚJO, Tiago Lustosa Luna de. A apreensão em flagrante do adolescente infrator pela ótica de quem lavra. Revista Jus Navigandi, Teresina, ano 15, n. 2627, 10 set. 2010. Disponível em: https://jus.com.br/artigos/17373. Acesso em: 30 out. 2016. 
2. BRASIL. Constituição da República Federativa do Brasil de 1988. Disponível em: http://www.planalto.gov.br/ccivil_03/Constituicao/Constituicao.htm. Acesso em: 25 out. 2016.

3. L. Lei $\mathrm{n}^{\circ}$ 8.069, de 13 de julho de 1990. Texto compilado. Dispõe sobre o Estatuto da Criança e do Adolescente e dá outras providências. Disponível em: http://www.planalto.gov.br/ccivil_03/leis/L8069.htm. Acesso em: 25 out 2016.

4. 4. _. Lei ${ }^{\circ}$ 10.436, de 24 de abril de 2002. Diário Oficial (da) República Federativa do Brasil, Brasília Reconhecimento da Língua de Sinais Brasileira como a língua natural de uma pessoa surda. Disponível em: http://www.dicionariolibras.com.br/website/artigo.asp?id=784. Acesso em: 30 out 2016;

5. 5._. Secretaria Especial de Direitos Humanos (SEDH). Sistema Nacional de Atendimento Socioeducativo - SINASE. Brasília: CONANDA, 2006.

6. 6. TOMATIS, Alfred. L'oreille et lavoix. Paris: Ed. Robert Laffont, 1975.

7. 7. DIZEU, L. C. T. B. e CAPORALI, S. A. A Lingua de Sinais Constituindo o Surdo como Sujeito. Educ. Soc., Campinas, vol. 26, n. 91, p. 583-597, Maio/Ago. 2005. Disponível em: http://www.cedes.unicamp.br. Acesso em 30 out. 2016.

8. 8. CORMEDI, M. A. Estudos sobre a Deficiência Auditiva e Surdez. Brasília - DF. Disponível em: http://lms.ead1.com.br/webfolio/Mod6625/estudos_sobre_a_deficiencia_auditiva_e_surdez_v2.pdf Acesso em 30 out. 2016.

9. 9. CARDOSO AHA, RODRIGUES KG, BACHION MM. (2006) Perception of persons with severe or profound deafness about the communication process during health care. Rev Latino-am Enfermagem 2006 julho-agosto; 14(4):553-60.

10. 10. BRUNSON, J.L. (2008) Your case will now be heard: sign language interpreters as problematic accommodations in legal interactions. Journal of Deaf Studies and Deaf Education February 2008.

11. 11. MCANNANY, K., (2011). With their own hands: a community lawyering approach to improving law enforcement practices in the deaf community in Valparaiso University Law Review. (pp. 875-925).

12. 12. PAUL, P. V. (2012). The horror of being Deaf and in prison. in Gallaudet University. Disponível in: https://deafinprison.com/2012/03/05/the-horror-of-being-deaf-and-in-prison/. Acesso em: 29 dez. 2016. 